Sign Systems Studies 49(3/4), 2021, 318-337

\title{
Cultures of the (masked) face
}

\author{
Gabriele Marino ${ }^{1}$
}

\begin{abstract}
What we generally regard as 'the face' should be semiotically understood not as something given and monolithic, but rather stratified - it is at least threefold: biological (face), physiognomic (expression), perceivable (visage) - and relational as it has to be put within a narrative in order to make sense. The face lies at the centre of a whole semiotic system, the form of life, revolving around the issue of identity (which the face - the visage, to be precise - embodies and still does not resolve). What we may call 'the natural face' is not, as common sense would suggest, the precondition of the 'culturalized' one (featured with modifications ranging from make-up and proper masks to surgery), but rather just one of the possible semiotic masks a person may choose to wear. At the same time, the mask does not have to be reduced to a deceptive device only (nor to be meant merely as a material object), being in fact at the centre of a more complex axiology. The classic veridictory square articulating the opposition between Being and Seeming may provide a suitable model for the semiotic square of 'visageness', so that we would have: Face, Disguise (the place of the mask proper), Fake, Anonymity. Based on these theoretical premises, the paper finally addresses popular music and outlines a provisional map of the pragmatics of the mask (subtractive vs. additive, ritualistic vs. continuous, material vs. virtual, mask as face vs. face as mask), as a suggestion for further studies.
\end{abstract}

Keywords: face; form of life; mask; semiotics; visage

In memory of Daniel Dumile

aka MF Doom (1971-2020)

\section{Introduction: Semiotics of the (threefold) face}

The face has been studied in a semiotic fashion: semioticians have been studying the face among other things - more often than not, in order to understand other things. Still, there is no such thing as 'the semiotics of the face. This is no surprise:

1 Department of Philosophy and Educational Sciences, University of Turin (UniTo), Italy; e-mail: gabriele.marino@unito.it. 
the face is such an immediate semiotic speaker that even semiotics may have fallen into the bias of not focusing on what seems so obvious - being such an immediate semiotic speaker, the face is hardly detachable from human communication as a whole. It is only when the face becomes less an obvious object that its "obtuse" as Barthes (1970) would call it - meaning unfolds; as, for instance, when it is modified, hidden, denied.

What in English we generally regard as 'the face' is at least three different things: (1) a biological surface, that makes it possible for (2) the sophisticatedly culturalized expressive mask of the human being to become (3) visible. We have not only the face (Lat. facies), but also the expression (vultus) and the visage (visus); in semiotic literature such a trichotomy is supported, for instance, by Magli (esp. 1995: 9-15; see also Fabbri 1995)2. The notion of the Actant (Greimas, Courtés 1982 [1979]: 5-6) deals with the fact that different tokens may play the same role and that the same token may embody different roles, which is the case with what we generically call 'the face': a single Actor embodying different Actantial roles. It is through (1) this body part that (2) the emotions codified in the physiognomic knowledge stratified during ages of biological evolution and cultural codification are being expressed, making it possible for (3) the persona to surface in the conjunction between the collective (our cultural grids) and the individual (each single subjectivity). In terms of Peirce's philosophy of the sign (CP 2.87), the singularity manifested would stand as the Firstness of the Representamen (visus), the material datum as the Secondness of the Object (facies) and the mechanism that links perceptions and expressions into a crystallized - but still customizable code as the Thirdness of the Interpretant (vultus); through the first, which may, but need not, coincide with the second, we reconnect to and reconstruct the third one.

The primacy of the face in the definition of 'the other' as a Subject has been posited by psychoanalysis ('the mirror stage' in Lacan 1949), researched by experimental psychology (the life-long studies of Ekman) and extensively problematized by anthropology (for a semiophile overview, see Affergan 2005[2003] $)^{3}$. A famous passage in Jakobson (1960: 377) shows, in a nutshell, how the face is never given, being in fact subject to complex (trans)cultural negotiation:

A missionary blamed his African flock for walking around with no clothes on. 'And what about yourself?' they pointed to his visage, 'are not you, too, somewhere naked?'. 'Well but that is my face.' 'Yet in us' retorted the natives, 'everywhere it is face'.

2 Needless to say, in common language the three terms are generally employed as synonyms.

3 Ekman (1978) proposed an early (para)semiotic - in the Peircean, Sebeokian sense - approach to face. Levinas (1961) considers what he calls 'the visage' so meaningful to mankind precisely due to its capability to convey the 'presence of the other' through what he calls 'the expression'. 
We consider meaningful anything equipped with what we recognize as a face; in turn, on the one hand, we assign a face to what we want to consider meaningful and, on the other hand, the face is so meaningful to us that we assign it even to meaningless things (which is the case in pareidolia). This process of facemaking, rooted in the gestaltic need to find familiar signs in reality, has been encoded by means of language, thus trespassing from the biological into the cultural, to the extent that we ended up living in a 'facial society' (Treusch-Dieter, Macho 1996); the proliferation of face signs in digital communication such as emoticons, emojis, selfies, filters is just one of the many corollaries ${ }^{4}$. To sum it up: anthropomorphization cannot help coming in via facialization.

The synecdoche (a part for the whole) of the body, the metonym (the concrete for the abstract) of the identity, the prosopopoeia (presentification, personification) of the individual, the face is where our sociality is grounded and it still keeps its role - the catalyst of the persona's signification - when it is subject to modification or occultation. Face cosmetics, disguise, masking, denial are strategies semiotics seizes for to confirm one of its foundational hypotheses: meaning-making never stems from an isolated piece of information, but rather is always relational and narrative $e^{5}$. Be it altered or hidden, the face signifies as it is set within a world of faces (proposed as natural and displayed in plain sight) and related to what it alludes to or stands for.

\section{Natural face and semiotic mask}

A fabric with floral fantasy makes it possible for a - faceless, indeed - Nude by Boubat (Floch 1985) to transition from the state of Nature into Culture, thus becoming a mythological figure by definition (i.e. subsuming the oppositive duality). Likewise, all the parafacial - more precisely, perifacial - devices such as make-up, haircut, beard styles, tattoos, implants, surgery, wearables and accessories (jewellery, headpieces, piercings, proper masks, etc.) make it possible to turn the face into the visage; namely, to display intervention into this body part so as to make it recognizable as culturalized ${ }^{6}$. What we keep calling simply 'the face' is

4 For pareidolia, see Stano 2021; for emoticons and emojis, see Marino 2015 (available as Marino, Gabriele 2015. :-) come emoticon. Più che semplici faccine. Doppiozero Feb. 9. https:// www.doppiozero.com/materiali/ovvioottuso/come-emoticon) and McCulloch 2019: 155-195. For selfies, see Del Marco 2015 (available as Del Marco, Vincenza 2015. Selfie. Forme e pratiche riflessive. il lavoro culturale Nov. 23. https://www.lavoroculturale.org/selfie-forme-e-praticheriflessive/vincenza-del-marco/2015/) and Leone 2018.

5 A recent discussion of this classic structuralist belief can be found in Violi 2018.

6 'Para-' and 'perifacial' are calques from Genette 1982; according to the French narratologist, paratexts are the 'thresholds of the text' that serve as its complementary annexes, a specific 
never the facies (with all due respect to doctors seeking signs of illness in the proverbial facies hippocratica), but always something profoundly culturalized: the

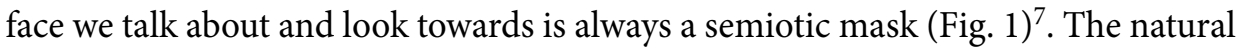
face is just a constructed 'degree zero' layer - to paraphrase Barthes 1947 - of our 'faciality' (Fr. visageité; Guattari 1979; Deleuze, Guattari 1980) ${ }^{8}$, selected among the many possibilities; in the wake of Goffman 1955, we may call this process of selection 'face-work'.

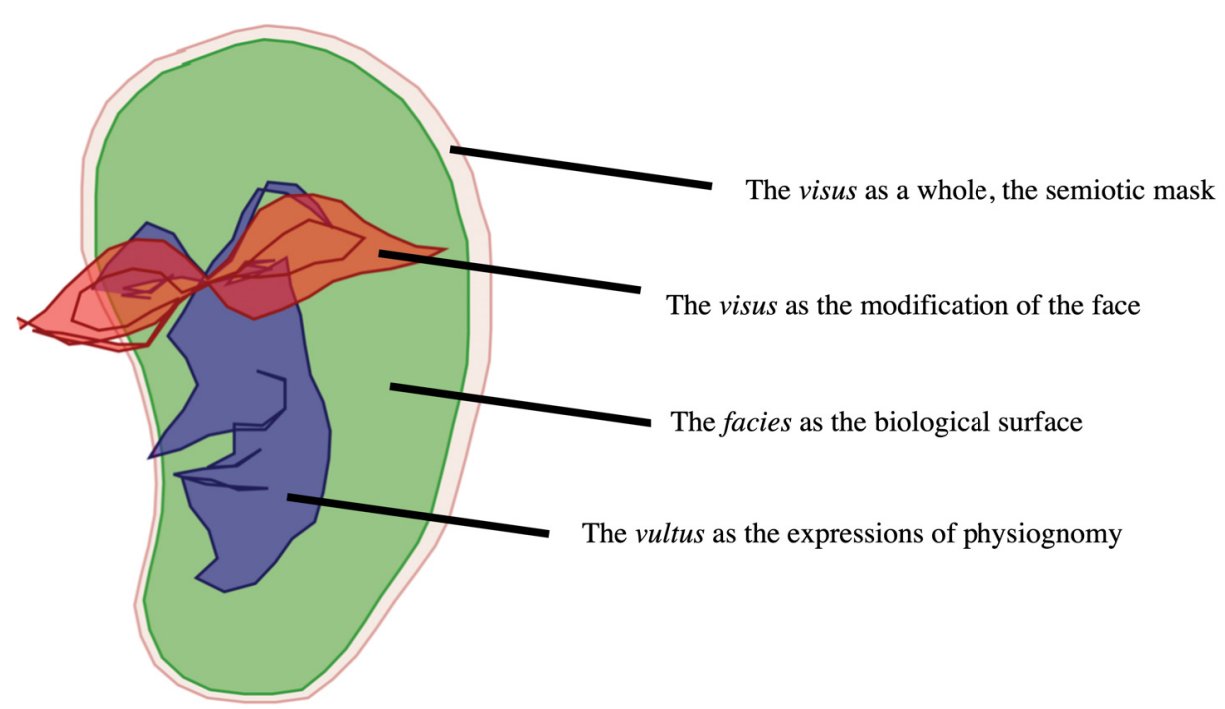

Figure 1. Stratification of the 'semiotic mask'.

category of which are peritexts, marked by spatial continuity with the text. From the Genettean notion of the epitext, i.e. paratext with no spatial continuity with the text, we may also derive the idea of 'epifaciality', as is the case with hands contributing to facial expressions (e.g. the facepalm), thus turning the face into the visage; see Marino 2020 (available as Marino, Gabriele 2020. Facepalm. Semiotica epifacciale della frustrazione. In: Leone, Massimo (ed.), Volti virali. Torino: FACETS Digital Press, 67-100. http://www.facets-erc.eu/wp-content/uploads/2020/05/ Massimo-LEONE-2020-Volti-virali-PDF-Editoriale-Compresso.pdf).

7 In a digital context we would talk of the avatar.

8 The notion has prominent political/juridical connotation as it is something of a heteronormative nature (see 'regime of visibility' and 'regime of enunciability' below), being a critique of the ontological, universalistic philosophy of the face by Levinas. 
In Greimassian terms the mask wants "the floor to be taken" (It. "vuole che una parola sia presa") by means of Enunciation (Damisch 1979: 789) ${ }^{9}$; it is a débrayage, a disengagement from the enunciation source - a consequence of any utterance which is being posited as its precondition - by means of articulating the categories of Person, Space and Time in discourse as 'They', 'There' and 'Then'. The face is an embrayage, the Meaning effect (Fr. effet de sens) ${ }^{10}$ of going back to the enunciation source where 'I' am saying something 'Here' and 'Now' (to 'You'); it is a re-turn, something reconstructable only ex post, identifiable as a marked place within the text where it folds back upon itself ${ }^{11}$.

In other terms, thanks to the fact that we can modify or cover the face, we need to establish the virtuality of another layer of meaning which would lie underneath and, at the same time, is a consequence of all the possible interventions and overlays. The face is not the precondition of the mask ${ }^{12}$ but, on the contrary, only thanks to the semiotic device of the mask can we eventually conceive a pre-semioticized, unmasked face: as "every visage is a mask" (Damisch 1979: 789), actually the "mask puts the face" on man (Affergan 2005[2003]: 315). The problem of the mask is "the problem of identity in general, in its social and cultural construction, attribution, display and transformation: the process of continuous meaning construction that Peirce called 'semiosis"' (Pollock 1995: 594). The maskface - and not, simply, the face mask - is the screen onto which the form of life hiding, revolving, arising behind it is being projected.

\section{Face and life}

The notion of 'form of life' (Germ. Lebensform) was first employed in a philosophical sense by Wittgenstein $(1953,1969)$. A form of life would be the condition of Being that makes meaning possible: the rules determining human behaviour should be understood only with reference to a specific form of life, which has determined them in the first place so as they would reflect it. Albeit never thoroughly explained by Wittgenstein, the term has achieved great success in philosophical discourse: it is a notion central to contemporary pragmatism

\footnotetext{
9 For Enunciation, see Greimas 1975, Greimas, Courtés 1982[1979]: 103-105.

10 See Greimas, Courtés 1982[1979]: 187-188.

11 The analysis of the blank, expressionless 'neutral mask' by Marsciani (1990, 1996), considered as a case of 'missing enunciation' (It. enunciazione mancante), is consistent with this logic.

12 As, for instance, in Levinas 1961; for a semiotic interpretation of his face philosophy, see Ponzio 2007.
} 
and, among others, Agamben. The latest developments of structural-generative semiotics recovered the notion as well; in 1991 Greimas suggested it as a topic for a seminar, which never took place, and Fontanille (1993) and other members of the Paris School developed it further (Landowski talked of 'lifestyle'; Latour, a philosopher close to Greimassian semiotics, of 'modes of existence').

According to Fontanille (2015: 260) forms of life are the "immediate constituent of the semiosphere", providing "a coherent deformation of the semiotic function" (Fontanille 2004: 103) "that affects all the levels of the generative trajectory of meaning of any discourse or semiotic universe: ranging from sensory and perceptual schemes to narrative, moral and axiological structures" (Fontanille 2004: 409) ${ }^{13}$. Influenced by the theories of embodiment ${ }^{14}$, as well as by the reflections of Greimas (1987) upon the 'aesthesia', Fontanille proposes a development of the narrative theory that links it to body and experience: a form of life is not only the consistency - a kind of macro-metaisotopy (isotopy being semantic recurrence) - that holds together a given narrative ${ }^{15}$; rather, a form of life is the semiotic norm that pervades and, in the first place, determines such narrative through its enactment, its bodily and existential translation into experience. To live according to a given form of life means to conform to a regulative model of action, to pursue a style of strategic behaviour aimed at achieving a result which is consistent with the foundational axiology. The form of life is exactly such a teleological projection from a set of premises to a set of consequences $^{16}$; it is no coincidence that Fontanille has been focussing so much on this notion, as he had already proposed, along with Zilberberg (Fontanille, Zilberberg 1998), a tensive model of semiotics.

Given that the form of life is what holds together all the possible enunciates, textual products or substantializations stemming from the very same semiotic

13 For the semiosphere, see Lotman 1984; for the Generative trajectory, Greimas, Courtés 1982 [1979]: 132-134. (Translations into English are mine, unless indicated otherwise; G. M.) 14 The theories of the extended mind, which include embodiment (or enactivism), were, in turn, influenced by phenomenology (Merleau-Ponty) so that they conceive cognition as an activity, rather than a capability, performed not only by the brain but through the whole body as situated in a given environment. The embodiment book which Fontanille references the most is Varela, Thompson, Rosch 1991.

15 A narrative generated in the deepest levels of axiology (set of values, Semiotic square), progressively anthropomorphized and articulated through Semio-narrative (Modalities, Narrative programs and Actantial roles) and Discoursive structures (Thematization and Figurativization as regards the semantic components; Actorialization, Temporalization and Spatialization as regards the syntactic components) and eventually manifested in the surface of text.

16 In these terms, the form of life may be conceived as what Eco (1976[1975]: 289-298) defines as 'ideology'. 
system, it is the metalevel that ensures intersemiotic translation (the mutual translatability between different matters, modes, media according to Jakobson 1959). The mask stands as a perfect Figural device (the pre-, protofigurative level within the Generative trajectory of meaning that is the place of intersemioticity, as the semantics of what would become the different Object-semiotics are all together and in mutual exchange) capable to condense a whole form of life ${ }^{17}$. Lotman (2002[1981]) developed such an intuition in a little-known essay of his: in the afterword to a German edition of Gogol's The Dead Souls he thoroughly explained how the masks made by Russian sculptor Kaplan were capable of translating the verbal images evoked in the novel into visual and haptic forms by developing, thanks to the unique sensitivity of the artist, the very same structural principles manifested through the very same figurative motives.

\section{Face and lie}

Claiming that the semiotics of the face has to be understood as a semiotics of the mask is not a philosophical gimmick as one unfamiliar with semiotic reasoning could think, but rather a methodological operation. Semiotics operates by overturning common sense, by building up general rules on the basis of what common sense generally regards - i.e. dismisses - as exceptions. Semiotics being a system of thought translated into an interdefined metalanguage (and being a whole wherein each single part is defined by its relationships with the others), there is simply no room for exceptions (single elements for which the general rule would not apply). If we know that nature is deeply culturalized and culture deeply naturalized (as Morin has maintained since the 1950s and the ontological turn in anthropology has been discussing since the 1990s), building our semiotic theory of the face on the basis of the common sense dichotomy between nature and culture would prevent us from truly comprehending the axiologies and ideologies of the face spread diachronically and diatopically ${ }^{18}$. If general semiotics, as posited by the famous,

17 The Figural is a crucial and yet underinvestigated notion in post-Greimassian semiotics. The term had already been employed, with different meanings, by authors such as Auerbach, Merleau-Ponty, Lyotard and it is only briefly addressed in Greimas, Courtés 1986: 91-93 (entry written by Zilberberg); as far as I am concerned, the best sources in point are Jacoviello 2012: 233-242 and Lancioni 2020: 146-152. The Figural may be conceived as a kind of Ur-metaform, where metaform is a "concept ([thinking = seeing]) that results from the linkage of an abstract notion ([thinking]) with a concrete source domain ([seeing])" (Sebeok, Danesi 2000: 196). Marino (2021a, 2021b) elaborates on the relationship between the Figural and the form of life with regard to music.

18 Still, such a dichotomy (natural vs. cultural - i.e. artificial - face) is an important drive 
provocative, tongue-in-cheek - and yet philosophically accurate - definition by Eco (1976[1975]: 7), aims at studying signs by studying "everything which can be used in order to lie", a semiotics of the face should study everything which can be used in order to "lie the face" (to make a lie of the face), to fake it, to mask it. To paraphrase Eco, we might say that if something cannot be used to hide the face, conversely it cannot be used to display it. The semiotics of the face is not a semiotics of what passes for the face plain and simple, but rather the semiotics of the visus, aimed at reconstructing how the expressive signs of the vultus are being displayed (or not) through the biological facies. The case where the visus conveying the vultus coincides with the facies - i.e. when the biological datum is perceivable and communicates as such - has to be understood as a 'mask degree zero'.

The face has been semiotically studied in connection with the portrait (Calabrese 1981), the self-portrait (Calabrese 2006), digital communication (Leone 2019) and digital pictorialization (Danesi 2016) and, more generally, as the sign congealing a whole aesthetic (Eco 2004, 2007). Barthes (1967) talked of the dress as "the mask of body" and compared the photographic portrait to a semiotic "death mask" (Barthes 1980). The semiotic approach reduces the face to the mask - as we have seen - and the mask to a deceptive device: semiotic theatrology (De Marinis 1982), aesthetics (Marin 1993), physiognomy (Eco 1984; Magli 1995) ${ }^{19}$, cosmetology (Magli 2013) and the semiotic analysis of literary ekphrasis (Magli 2016) have focused on the face mainly to unmask it, to understand when, where and how it would be faking us ${ }^{20}$. In Greimas and Courtés (1982[1979]: 67-68) the mask is addressed only twice: in connection with the Deceiver (the trickster of mythology, who often wears it) and in connection with the moment of the Qualifying test when the Sender hides "under the mask of the Adversary". A reductionist perspective of this kind (mask $=$ deception), profoundly influenced by the episteme of the Classical Age (Damisch 1979: 788), would be best suitable for handling only texts, and not entire forms of life, as we can definitely identify a strategy of some sort, but we would have trouble judging whether and according to which level of semiosis a mask would 'tell the truth' or 'be authentic' (or not)

in both perceptual and cultural phenomena. The hypothesis of the 'uncanny valley' by Mori (see Surace 2021), that humanoids imperfectly resembling human features would provoke a feeling of eerie familiarity, lies on the frontier between the natural and the artificial: we find a simulacrum, a mask (humanoid), where we would expect to find a face (human being).

19 The text by Eco is the reprint of his Preface to the book Il Lavater portatile (con i disegni di Franco Testa), an anastatic edition, issued by the publisher Moizzi in Milan, of Johann Kaspar Lavater's physiognomic treatise from 1788.

20 Reviews of the semiotic approaches to the mask may be found in Proschan 1983, Leone 2020, Gramigna 2021. 
as regards the physical person who would be wearing $i^{21}$. My proposal is to maintain the semiotic primacy of the mask over the face, to broaden the category of mask (not merely a physical object but rather a semiotic strategy) and not to reduce the mask to only one among its possible valorizations and uses. The classic Veridictory square generated from the opposition between Being and Seeming (Greimas, Courtés 1982[1979]: 369) may be fruitfully applied in order to identify the axiologies of 'visageness' (see Fig. 2):

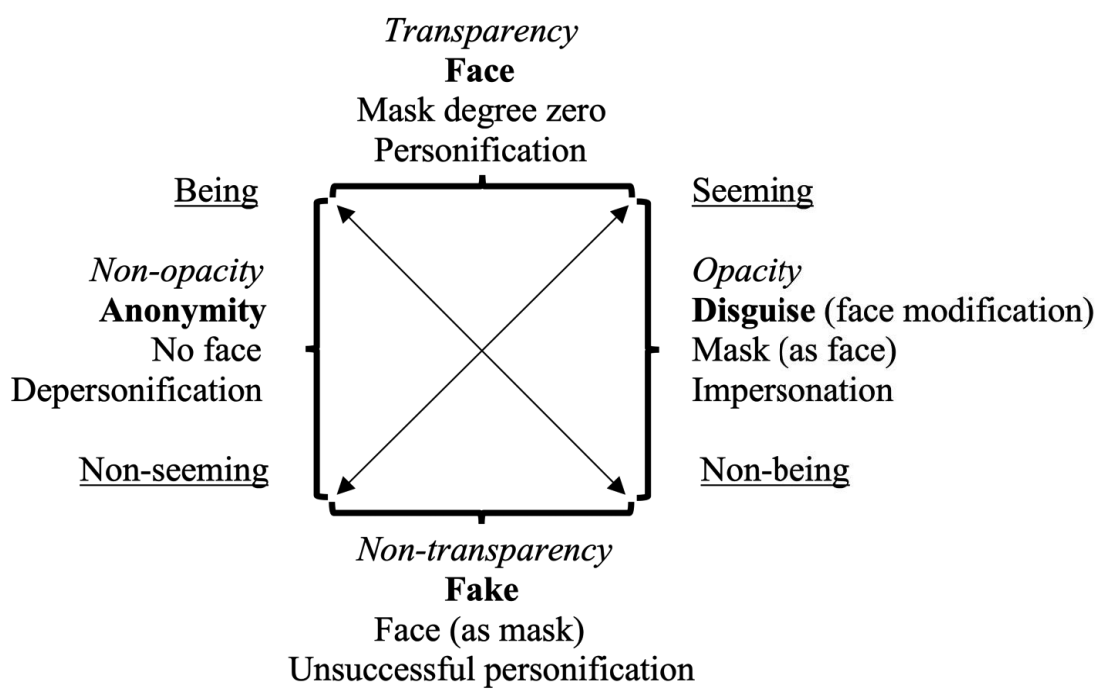

Figure 2. The semiotic square of 'visageness'.

- Truth $\rightarrow$ Face (transparency, mask degree zero, personification);

- Lie $\rightarrow$ Disguise (opacity, mask as face, impersonation);

- Falsehood $\rightarrow$ Fake (non-transparency, face as mask, unsuccessful personification);

- Secret $\rightarrow$ Anonymity (non-opacity, no face, depersonification) ${ }^{22}$.

21 Needless to say, the relationship between face and mask as regards the issue of identity is a classic philosophical theme, especially in the 20th century, when the idea of a fragmented identity prominently emerges; e.g. according to Gurisatti (2006: 222), Nietzsche's Zarathustra would programmatically be nothing more than a "shallow dance of masks-without-face, formswithout-content, appearances-without-essence".

22 The opposition between depersonification (It. incognito, annullamento dellidentità) and impersonation (travestimento, sostituzione di identità) is drawn from Damisch 1979: 776. According to Sbisà (2002: 14), "the definition of Falsehood is controversial, but we can explain it by referring to a Sender that judges a statement produced by the Subject as 'It is not this way, 
We can think of a semiotics of the face focusing on the very face in itself - for instance, a semiotics of its representation (which is the semiotics of the portrait). Yet when we aim at building a semiotics of the face within the framework of the semiotics of culture (dealing with the face within a given semiosphere, as a cultural unit of a given encyclopaedia ${ }^{23}$ ), we cannot consider it only as a representational, visual and haptic token ${ }^{24}$. When we meet someone new and get to know their name, still the only identity we are told about is the anagraphic one. Likewise, when we see the face of someone new, we do not know the person to whom it belongs (who is behind it and so before us). In other terms, the face per se means nothing, reveals no mystery, unless it turns into a visage, the semiotic mask: in order to make sense, it has to become a sign, to stand "to somebody for something in some respect or capacity" (CP 2.228). Otherwise it would merely represent the possible starting point, supposedly of the indexical kind, for making inferences rooted in the biological; let us think of the phantasmagoria prompted by Lombroso, who founded his criminology by grounding it in positivistic, yet pseudoscientific determinism: a true conspiracy of bodily signs. We have, in turn, to question ourselves: are we immune to such conspiratorial temptation?

\section{Facets of the mask}

The face can be dealt with according to different 'regimes of visibility' ${ }^{25}$, different degrees of transparent immediacy or opacity ${ }^{26}$ : the former dimension deals with the possibility of recognition (i.e. positive comparison between the new token and the known type), so that we would be allowed to reconnect the perceivable - the face or its delegate ${ }^{27}$ - to a biological datum and anagraphic name; the latter deals with the impossibility of accomplishing such a task. We can be shown a perceivable

and it does not seem this way', thus sanctioning its evident falsehood" (Sbisà, Marina 2002. La semiotica narrativa di A.J. Greimas. Concetti principali e istruzioni per l'uso was retrieved from https://www2.units.it/sbisama/it/didattica/semiodisp_2.PDF). Disguise/impersonation may be conceived also as 'mimicry' (Caillois 1958).

23 For the encyclopaedia, see Eco 1986[1984].

24 Outside semiotics, a comprehensive approach of this kind is being pursued by Belting (2013).

25 A notion proposed by Foucault, with regard to power, and developed in the texts by Deleuze (1986) interpreting Foucault.

26 Opposite terms proposed by Bolter and Grusin (1999); Marin (1994) proposes similar categories within a proper semiotic perspective.

27 The term 'delegate' is inspired by Latour's reworking of enunciation theory (see Latour 1998). 
that coincides with the natural face and we can be shown a face culturally modified according to different degrees of intervention, with a special spot assigned to the device that covers the face, hiding it partially or totally ${ }^{28}$.

In a world of over-representation and over-exposition, face occultation (the mask as the face delegate) or face denial (no face nor delegate available) are remarkable semiotic operations that stand for a clear identity statement, opening to a whole set of valorizations; as a matter of fact, the mask is not so much polysemic but polypragmatic: it has different meanings because of different uses. It can be either imposed or chosen (both bandits and hostages wear it, but for different reasons), it can be used to deceive or address; it is the distinctive feature of the criminal, the enemy, the bad guy, the traitor, the spy, the coward, the victim, the (super)hero. In other terms, the semiotic device of the mask can be used subtractively (it denies the biological face), in order not to be recognized (to hide oneself from the outside world), as much as additively (it is superimposed onto the face, serving as its delegate), precisely to be icastically recognized by means of emphasizing some features or creating alternative ones (the mask does cover the face, but in order to amplify/reveal it ${ }^{29}$. Just like every sign, and in the respect of being itself a kind of "sign par excellence", the mask is transparent and opaque at the same time, it is both 'a thing' and 'a sign'; as a thing it may cover what, as a sign, it would reveal, so that there may be no actual relationship between what the mask is hiding and what it is standing for, what it is signifying (Damisch 1979: 785). The mask, whatever it may be, stands as a mythopoietic mechanism that, by questioning common sense identity (it prevents from linking the Enunciator with an Empirical author) and triggering detection (we are prone to seek any clue of the wearer's form of life within their enunciations), suggests a heterotopy of values. A Practical-referential valorization is opposed to a Utopian-existential one; with the caveat that the former is easily at risk of being reconducted to the latter (in order

28 Here we may suggest an opposition between bandanas (covering the nose and the mouth) and masks (leaving the nose and the mouth uncovered). While bandits use the former type to disguise their identities, the latter type is "designed less to disguise than to signal that disguising is taking place, a semiotic process that is effective only to the extent that it indexes the culturally conventional sign of identity: the eyes" (Pollock 1995: 595); let us think of Diego de la Vega/Zorro's mask and Superman/Clark Kent's glasses. In the constitutive asymmetry of these two partial masks (covering some parts of the face, while leaving others uncovered), in their capability to disrupt the features of the body in opposition to the natural symmetry of the biological face, we may recall the individualistic élan Simmel (1901) ascribes to all irrationalistic traits.

29 In the wake of Bouissac's studies on clowns, Ogibenin (1975: 5) focuses on the mask as a metasemiotic instrument capable of generating "isolation and alienation" by means of "the hypertrophying of the physical constants of the human face". 
to serve as the mouthpiece for an alternative to the dominant axiology, the Subject disguises themselves so as to be unrecognizable).

Even though its iconic status, stricto sensu, has been questioned to the benefit of a more systemic (i.e. not only visual), performance-oriented approach (Salvatore 2015,2018 ), the history of popular music is definitely an iconography of famous faces at display, where cult figures wearing masks also exist ('masked musicians' is literally $a$ thing in our shared encyclopaedia) ${ }^{30}$. Whereas the study of masks in popular music is little more than a footnote - three lines in all - within what we may call general maskology (Bell 2010: 1), the semiotics thereof is auroral. Reyes (2021) analysed the 542 covers of the records published in 1988 and in 2018, according to Wikipedia, and found that 32 of them display an 'occluded face'; by blending an automatic-quantitative approach, in the framework of Manovich's cultural analytics, and hand-made typologization, in the framework of a qualitative research consistent with semiotic analysis, he distinguished between four types of facial obstruction (due to a mask, a visual effect, the pose of the body, the framing of the image) and identified two main axes of visual strategy (from a maximum of face shown to a maximum of face hidden, from a maximum of distorted face to a maximum of sharp face). As a matter of fact, popular music represents a promising field of research in the framework of a semiotics of the face; hence, the following considerations include cues for further study in this perspective.

The mask has its own aspectuality - it may be worn in coincidence with the performance (punctual) or it can be employed continuously, as offstage as onstage (durative): in the former case the mask, a prop contributing to showmanship, is generally employed to define characters/alter egos and mark the performance as a ritual (a prototype in pop-rock music may be Arthur Brown's face painting and burning helmet from 1968); in the latter case it is literally the metonym of a form of life which is being pursued all the way (as in the case of the French electronic duo Daft Punk with their signature robot-like helmets). An extreme outcome of this totalizing logic is what we may call impersonation: a kind of 'self-Doppelgänger-ism' (or 'Andy Kaufman effect') where the performer is not merely performing, not just playing a part, but rather living it, without breaking character (a notable example

30 See: Masked Musicians. Wikipedia. https://en.wikipedia.org/wiki/Category:Masked_musicians (category page created in 2011). The Internet is filled with popular lists and polls about masked, disguised and/or anonymous musicians, but proper journalistic inquiries and scholarly articles are sporadic. An exception is Reynolds 2021, written after the announcement of the death of the American masked rapper and producer Daniel Dumile aka MF Doom (Reynolds, Simon 2021. Mask Up. Inside pop and rock history's obsession with disguise. Tidal. com. Jan. 14; the source was retrieved from https://tidal.com/magazine/article/pop-maskhistory/1-76368). 
in popular music may be Watkin Tudor Jones aka Ninja's South African 'zef' hip hop group Die Antwoord).

The mask can be a material object or it can be immaterial. The latter is the case with fictional performers who embody the musical Enunciator (most notably, socalled virtual bands, from the Chipmunks or Gorillaz cartoons to vocaloid Hatsune Miku): the mask is not a device that hides a face - it is a mask literally applied to no one - but rather the only face we are being shown (which reinforces our theory of the semiotics of the face as, first and foremost, a semiotics of the mask); in this case the mask is the face ${ }^{31}$. The flipside is when the face becomes nothing more than a mask; we know the performers - we know their face - and still we do not know them at all. As a matter of fact, some figures happen to be so much 'wrapped in legend' that their oeuvre does overcome in accountability their personal story, to which we are denied access (from the "inventor of improvisation" Buddy Bolden, a kind of Homer for jazz music, to the lugubrious singer-songwriter Jandek). The face may be also turned into a mask by means of its multiplication and consequent resemantization (as in the case of the chameleonic English rock star David Bowie) or desemantization (as in the case of the Italian singer Mina, whose face is subject to countless modifications and stylizations, or the English electronic musician Aphex Twin, whose face is prosthetically and digitally transformed into horrific appearance and obsessively reproduced on album covers and in video clips, in a kind of grotesque parody of pop music iconicism).

As it is easy to understand, facial discourse - the discourse of the face - may be doubled by the name and voice discourses, as names and voices can be plainly displayed, variously modified and covered or totally hidden in a very similar way as the face can. In designing a coherent form of life, in pursuing a project of life, it is no coincidence that stage names are used, appearances are modified, voices altered. In general terms, in the 'regime of enunciability'32 chosen by the performer, the name can be articulated in transparency (birth name), as alternative (pseudonym) or competing/coexisting (heteronym) with regard to the anagraphic datum, or it can be totally obliterated (anonymity) ${ }^{33}$.

31 We may fairly apply this definition also to the cases of "the continuous mask".

32 Again, a notion proposed by Foucault, with regard to law, and developed by Deleuze (1986).

33 For the semiotics of anonymity, see Thibault 2016 as well as Maani 2018 (available as Maani, Sitti [alias Leone, Massimo] 2018. I giga di Gige. L'impatto dell'anonimato nella comunicazione contemporanea. Rivista Italiana di Filosofia del linguaggio. http://www.rifl.unical.it/index.php/ $\mathrm{rifl} /$ article/view/520). The name has been a subject of semiotic inquiry since the prehistory of the discipline (philosophers of Ancient Greece, Hobbes etc.), as the act of naming is perhaps the most powerful semiotic act of all. For a semiotics of the face, understood as a semiotics of the mask (and, therefore, of identity), names are quite a promising topic; especially with regard to the notion of 'embodied name identity' (Pilcher 2015). 


\section{Conclusion: The face as semiotic conspiracy}

The face is the human communication palimpsest par excellence and yet the semiotic approach warns us against matching it to identity offhand. When we are shown someone's face we are not automatically granted access to their identity (as if identity were to be conceived as something given and stable, to be simply uncovered, as if it were like an ID with name, picture and signature). We may still lack all the meaningful relationships interweaving texts and practices. The face, the main identity mark along with the person's name and voice (the three features composing a kind of identity plexus) ${ }^{34}$, asks to be set within a discoursive network in order to work semiotically (see Table 1). We may be tempted to stick to the idea of reading the face as part of a somewhat simple, even universal code, the one linking us with the biological world, the one of physiognomic determinism; still, luckily, our semiotic hunger makes us unsatisfied with such codicality, as we chase not only the face but also what is behind it and what is being conveyed through it: what makes a face what the face in general and this one face in particular is to us.

We are obsessed by what we do not know, by what is missing: what is beyond the door, off the camera, behind the mask. We put every clue - every sign - we have got under a magnifying glass and we connect them to one another in order to make sense of what we are experiencing, so as to reconstruct what is not here from what is here, an absence through a presence. We are naturally - semiotically led to jump from one level to another, from the authenticity of artistic expression to the authenticity of experience, from the aesthetic to the existential. We want to find in the textualized authorship (Greimas' Enunciator, Eco's Model author, etc. $)^{35}$ not only the sincerity, the genuineness of the text, but also its truthfulness. Each possible identity token (within the texts, in both mediated and non-mediated presence) becomes a metatext for the other ones, so that the identity narrative may progressively cohere into a persona.

34 They seem to be "privileged signs of identity that embarrass Western culture every time a game of camouflage, of masking or elision tends to weaken, displace, or even undo the identification devices" (Bonelli 2004: 9, quoted in Calefato 2006: 75). In fact, Pilcher (2015: 765) notices that the one linking "names, identity and the body" together is still "a neglected relationship".

35 See, respectively, Greimas, Courtés 1982[1979]: 105 and Eco 1979: 60-66. 
Table 1. Dimensions at stake in the identity plexus.

\section{VISUAL DELEGATE}

- Semiotic mask (Culturalized face)

- Natural face

- Modified face

- Covered/Hidden face (mask)

- Denied face (no face, no mask)

\section{REGIME OF VISIBILITY}

- Transparency (possibility to be recognized)

- Opacity (impossibility to be recognized)

- Hypervisibility/Amplification/Multiplication (will to be recognized)

\section{NOMINABLE DELEGATE / REGIME OF ENUNCIABILITY}

- Birthname

- Pseudonym

- Heteronym

- Anonymity

\section{EXTROVERSIVE DIMENSIONS}

- Metatextual narrative (autobiography)

- Mediated presence (audiovisual)

- Non-mediated presence (live performance, face to face interaction)

"Outside the text, [there is] no salvation" Greimas (1975: 25) ruled, echoing Derrida's (1967: 227) "There is not outside-text"; and still the text is not enough, as our semiotic élan is centrifugal: in interacting with the texts, we seek the guarantee that, through them, it is not only a textual persona but rather a real person who is speaking to us about their - real or possible - world ${ }^{36}$. Interpretation becomes investigation: a process of reconstruction, unearthing, uncovering, revelation where we hope everything holds together and eventually makes sense. Again, it is a conspiracy, but, this time, of the semiotic kind. The semiotics thereof shall be directed at comprehending whether, how and to which extent does 'the face' plot against itself: whether, how and to which extent, does the visage semiotically works against the face and its expression - turning into the semiotic mask.

36 On the notion of 'possible world', see Eco 1978, 1979: 122-173. 
Acknowledgements: This article results from a project that has received funding from the European Research Council (ERC) under the European Union's Horizon 2020 research and innovation programme (Grant agreement No 819649 - FACETS). The author would like to thank Simon Reynolds for the fruitful exchange of views.

\section{References}

Affergan, Francis 2005[2003]. Modelli antropopoietici della Maschera. In: Figure dell'umano. Le rappresentazioni dellantropologia. Roma: Meltemi, 307-334.

Barthes, Roland 1947. Le degré zéro de l'écriture. Combat août: 2.

Barthes, Roland 1967. Système de la mode. Paris: Seuil.

Barthes, Roland 1970. Le troisième sens: notes de recherches sur quelques photogrammes de S. M. Eisenstein. Cahiers du cinéma 222: 12-19.

Barthes, Roland 1980. La chambre claire. Note sur la photographie. Paris: Cahiers du Cinéma-Gallimard-Seuil.

Bell, Deborah 2010. Mask Makers and Their Craft: An Illustrated Worldwide Study. Jefferson: McFarland.

Belting, Hans 2013. Faces: Eine Geschichte des Gesichts. München: Beck.

Bolter, Jay David; Grusin, Richard 1999. Remediation: Understanding New Media. Cambridge: The MIT Press.

Bonelli, Elena (ed.) 2004. Segni particolari. L'immagine del viso, l'immaginario del nome proprio. Urbino: QuattroVenti.

Caillois, Roger 1958. Les jeux et les hommes. Le masque et le vertige. Paris: Gallimard.

Calabrese, Omar 1981. La sintassi della vertigine: sguardi, specchi, ritratti. Versus 29: 3-31.

Calabrese, Omar 2006. L'art de l'autoportrait. Paris: Citadelles \& Mazenod.

Calefato, Patrizia 2006. Il nome, il volto. In: Calefato, Patrizia (ed.), Che nome sei? Nomi, marchi, tag, nick, etichette e altri segni. Roma: Meltemi, 43-77.

CP = Peirce, Charles S. 1931-1958. Collected Papers of Charles Sanders Peirce. Cambridge: Harvard University Press. (Vols. 1-6, Hartshorne, Charles; Weiss, Paul, eds.; vols. 7-8, Burks, Arthur Walter, ed.) [In-text references are to CP, followed by volume and paragraph numbers.]

Damisch, Hubert 1979. Maschera. (Malvano, Maria Vittoria, trans.) In: Romano, Ruggiero (ed.), Enciclopedia Einaudi. Vol. 8: Labirinto-Memoria. Torino: Einaudi, 776-94.

Danesi, Marcel 2016. The Semiotics of Emoji: The Rise of Visual Language in the Age of the Internet. New York: Bloomsbury Academic.

De Marinis, Marco 1982. Semiotica del teatro. L'analisi testuale dello spettacolo. Milano: Bompiani. https://doi.org/10.2307/1772329

Deleuze, Gilles 1986. Foucault. Paris: Minuit. https://doi.org/10.5040/9781350252004

Deleuze, Gilles; Guattari, Félix 1980. Mille plateaux. Capitalisme et Shizophrénie 2. Paris: Minuit.

Derrida, Jacques 1967. De la grammatologie. Paris: Minuit.

Eco, Umberto (ed.) 1978. Versus 19-20 (Semiotica testuale: mondi possibili e narratività). Eco, Umberto 1976[1975]. A Theory of Semiotics. Bloomington: Indiana University Press. Eco, Umberto 1979. Lector in fabula. La cooperazione interpretativa nei testi narrativi. Milano: Bompiani. 
Eco, Umberto 1984. Il linguaggio del volto. In: Sugli specchi e altri saggi. Milano: Bompiani, 45-54.

Eco, Umberto 1986[1984]. Semiotics and the Philosophy of Language. Bloomington: Indiana University Press.

Eco, Umberto 2004. Storia della bellezza. Milano: Bompiani.

Eco, Umberto 2007. Storia della bruttezza. Milano: Bompiani.

Ekman, Paul 1978. Facial signs: Facts, fantasies, and possibilities. In: Sebeok, Thomas Albert (ed.), Sight, Sound, and Sense. Bloomington: Indiana University Press, 124-156.

Fabbri, Paolo 1995. Difformità del viso. In: Brusatin, Manlio; Clair, Jean (eds.), Identità e alterità: figure del corpo 1895-1995. La Biennale di Venezia 46, Esposizione internazionale d'arte. Venezia: Marsilio.

Floch, Jean-Marie 1985. Un nu de Boubat. Sémiotique poétique et discours mythique en photographie. In: Petites Mythologies de l'Oeil et de l'Esprit: Pour une Semiotique Plastique. Paris, Amsterdam: Hadès-Benjamins, 21-38. https://doi.org/10.1075/as.1

Fontanille, Jacques 1993. Les formes de vie. Présentation. RSSI-Recherches Sémiotiques/ Semiotic Inquiry 13(1/2): 5-12.

Fontanille, Jacques 2004. Figure del corpo: per una semiotica dell'impronta. Roma: Meltemi.

Fontanille, Jacques 2015. Formes de vie. Liège: Presses universitaires de Liège. https://doi. org/10.4000/books.pulg.2207

Fontanille, Jacques; Zilberberg, Claude 1998. Tension et signification. Liège: Mardaga.

Genette, Gérard 1982. Palimpsestes. La littérature au second degré. Paris: Seuil.

Goffman, Erving 1955. On face-work: An analysis of ritual elements in social interaction. Psychiatry: Journal for the Study of Interpersonal Processes 18: 213-231. https://doi.org /10.1080/00332747.1955.11023008

Gramigna, Remo 2021. Le forme della maschera: aspetti semiotici della manipolazione del volto e della plasticità dell'apparenza. Lexia 37-38: 121-140.

Greimas, Algirdas Julien 1975. L'Énonciation (une posture épistémologique). Significação: 9-25. https://doi.org/10.11606/issn.2316-7114.sig.1974.90115

Greimas, Algirdas Julien 1987. De l'imperfection. Périgueux: Éditions Pierre Fanlac.

Greimas, Algirdas Julien; Courtés, Joseph (ed.) 1982[1979]. Semiotics and Language: An Analytical Dictionary. Bloomington: Indiana University Press.

Greimas, Algirdas Julien; Courtés, Joseph (ed.) 1986. Sémiotique: Dictionnaire raisonné de la théorie du langage, II. Compléments, débats, propositions. Paris: Hachette.

Guattari, Félix 1979. Visagéité signifiante, visagéité diagrammatique. In: L'inconscient machinique: essais de schizo-analyse. Fontenay-sous-Bois: Encres/Recherches, 79-116.

Gurisatti, Giovanni 2006. Dizionario fisiognomico. Il volto, le forme, l'espressione. Macerata: Quodlibet.

Jacoviello, Stefano 2012. La rivincita di Orfeo. Esperienza estetica e semiotica del discorso musicale. Mimesis: Milano-Udine.

Jakobson, Roman 1959. On linguistic aspects of translation. In: Brower, Reuben Arthur (ed.), On Translation. Cambridge: Harvard University Press, 232-239. https://doi. org/10.4159/harvard.9780674731615.c18

Jakobson, Roman 1960. Linguistics and poetics. In: Sebeok, Thomas Albert (ed.), Style in Language. Cambridge: The MIT Press, 350-377. 
Lacan, Jacques 1949. Le Stade du miroir comme formateur de la fonction du Je, telle qu'elle nous est révélée dans l'expérience psychanalytique. Revue française de psychanalyse 13(4): 449-455.

Lancioni, Tarcisio 2020. E inseguiremo ancora unicorni. Alterità immaginate e dinamiche culturali. Sesto San Giovanni (MI): Mimesis.

Latour, Bruno 1998. Petite philosophie de lénonciation. In: Basso, Pierluigi; Corrain, Lucia (eds.), Eloquio del senso. Dialoghi semiotici per Paolo Fabbri. Milano: Costa \& Nolan, 71-94.

Leone, Massimo 2018. Semiotics of the selfie: The glorification of the present. Punctum 4(2): 33-48. https://doi.org/10.18680/hss.2018.0018

Leone, Massimo 2019. The semiotics of the face in digital dating: A research direction. Digital Age in Semiotics \& Communication 2: 18-40. https://doi.org/10.33919/ dasc.19.2.2

Leone, Massimo 2020. The semiotics of the medical face mask: East and West. Signs \& Media 1: 40-70. https://doi.org/10.1163/25900323-12340004

Levinas, Emmanuel 1961. Totalité et Infini: essai sur l'extériorité. La Haye: Nijhoff.

Lotman, Juri 1984. O семиосфере. [On the semiosphere.] Sign Systems Studies 17: 5-23.

Lotman, Juri 2002[1981]. Маска в художественном мире Гоголя и маски Анатолия Каплана. [Mask in an artistic world of Gogol, and the masks of Anatoli Kaplan.] Sign Systems Studies 30(2): 695-705. https://doi.org/10.12697/SSS.2002.30.2.20

Magli, Patrizia 1995. Il volto e lanima. Fisiognomica e passioni. Milano: Rizzoli.

Magli, Patrizia 2013. Pitturare il volto. Il trucco, l'arte, la moda. Venezia: Marsilio.

Magli, Patrizia 2016. Il volto raccontato. Ritratto e autoritratto in letteratura. Milano: Raffaello Cortina.

Marin, Louis 1993. Masque et portrait. Urbino: CISeL-Centro Internazionale di Semiotica e Linguistica (Documents de travail et pré-publications 226, settembre, serie F).

Marin, Louis 1994. De la representation. Paris: Gallimard-Seuil.

Marino, Gabriele 2021a. The form of life of sanctity in music beyond hagiography: The case of John Coltrane and his "Ascension". International Journal for the Semiotics of Law. https://doi.org/10.1007/s11196-021-09829-7.

Marino, Gabriele 2021b. Il ghigno di Aphex e altre maschere: Volti del transumano in musica. Lexia 37-38: 197-216.

Marsciani, Francesco 1990. La maschera neutra. Carte semiotiche 7: 146-160.

Marsciani, Francesco 1996. Il volto neutralizzato. In: Fabbri, Paolo (ed.), Su la maschera Catalogo del XVII Festival internazionale del giallo e del mistero. Milano: Mondadori.

McCulloch, Gretchen 2019. Because Internet: Understanding the New Rules of Language. New York: Riverhead Books.

Ogibenin, Boris L. 1975. Mask in the light of semiotics: A functional approach. Semiotica 13(1): 1-9. https://doi.org/10.1515/semi.1975.13.1.1

Pilcher, Jane 2015. Names, bodies and identities. Sociology 50(4): 764-779. https://doi. org/10.1177/0038038515582157

Pollock, Donald 1995. Masks and the semiotics of identity. The Journal of the Royal Anthropological Institute 1(3): 581-597. https://doi.org/10.2307/3034576 
Ponzio, Augusto 2007. Differenza tollerata ed eccedenza del volto. In: Fuori luogo. L'esorbitante nella riproduzione dell'identico. Roma: Meltemi, 97-103.

Proschan, Frank 1983. The semiotic study of puppets, masks, and performing objects. Semiotica 47(1-4): 3-44.

Reyes, Everardo García 2021. Face value: Analyzing and visualizing facial data. Lexia 37-38: 467-483.

Salvatore, Gianfranco 2015. Icone in azione. Il Pop e il Rock come drammaturgie. H-ermes. Journal of Communication 4: 201-232.

Salvatore, Gianfranco 2018. Il teatro musicale del rock. Avanguardie, frontmen, light-show. Roma: Stampa Alternativa.

Sebeok, Thomas Albert; Danesi, Marcel 2000. The Forms of Meaning: Modeling Systems Theory and Semiotics. Berlin: Mouton de Gruyter. https://doi.org/10.1515/ 9783110816143

Simmel, Georg 1901. Die ästhetische Bedeutung des Gesichts. Der Lotse. Hamburgische Wochenschrift für deutsche Kultur 1: 280-284.

Stano, Simona 2021. Facing food: Pareidolia, iconism, and meaning. Lexia 37-38: 487-501. Surace, Bruno 2021. Semiotica dell'Uncanny Valley. Lexia 37-38: 359-380.

Thibault, Mattia 2016. Trolls, hackers, anons: Conspiracy theories in the peripheries of the web. Lexia 23-24: 387-408.

Treusch-Dieter, Gerburg; Macho, Thomas (eds.) 1996. Medium Gesicht: Die faciale Gesellschaft. Berlin: Elefanten.

Varela, Francisco J.; Thompson, Evan; Rosch, Eleanor 1991. The Embodied Mind: Cognitive Science and Human Experience. Cambridge: The MIT Press. https://doi.org/10.7551/ mitpress/6730.001.0001

Violi, Patrizia 2018. Dalla nave di Teseo al campanile di Venezia. Una prospettiva semiotica sulla identità. Rivista Italiana di Filosofia del Linguaggio 1. DOI: 10.4396/SFL201904.

Wittgenstein, Ludwig 1953. Philosophical Investigations. Oxford: Blackwell.

Wittgenstein, Ludwig 1969. On Certainty. New York: Harper.

\section{Культуры лица (в масках)}

То, что мы привыкли считать «лицом», с семиотической точки зрения является не чем-то определенным и монолитным, а имеет, по меньшей мере, тройную природу: биологическое (лицо), физиогномическое (выражение), воспринимаемое (визаж). В то же время лицо имеет относительный характер, так как несет смысл, лишь будучи включенным в повествование. Лицо является центром всей семиотической системы - формы жизни, вращающейся вокруг идентичности, которую лицо, точнее, визаж, воплощает и до сих пор не решает. То, что мы называем «естественным лицом», не является, как можно подумать, предпосылкой для возникновения «культурного лица» (включающего модификации от макияжа и масок до хирургии), а скорее служит одной из возможных семиотических масок, которые может выбрать человек. В то же время маска не должна рассматриваться только как способ обмана (или как материальный объект), в сущности находясь в центре более сложной аксиологии. Классический семиотический квадрат, противопоставляющий «быть» 
и «казаться», может стать основой для семиотического квадрата лица, включающего собственно Лицо, Маскировку (место маски), Подделку и Анонимность. Основываясь на этих теоретических предпосылках, статья обращается к популярной музыке и предлагает примерную карту прагматики маски (вычитание vs прибавление, ритуальное vs непрерывное, материальное vs виртуальное, маска как лицо vs лицо как маска) в качестве основы для дальнейших исследований.

\section{(Maskiga) näo kultuurid}

Seda, mida üldjuhul peetakse 'näoks', ei tohiks semiootiliselt mõista millegi antu ega monoliitsena, vaid pigem kihistununa - see on vähemalt kolmekordne: bioloogiline (nägu), füsiognoomiline (ilme), tajutav (pale) - ning suhtumuslikuna, sest sellele mõtte andmiseks tuleb see paigutada narratiivi. Nägu asub terve semiootilise süsteemi, elu vormi, keskel, keereldes identiteediküsimuse ümber (mida nägu - või täpsemalt, pale - küll kehastab, ent millele siiski lahendust ei anna). See, mida me võime nimetada 'looduslikuks näoks' ei ole 'kultuurilise näo' (mis esineb modifikatsioonidega, mis ulatuvad jumestusest päris maskide ja kirurgimaskini) eeltingimus, nagu argimõistus võiks välja pakkuda, vaid lihtsalt üks võimalikest semiootilistest maskidest, mida inimene võib otsustada kanda. Samal ajal ei pea maski taandama üksnes petmisvahendiks (ega pidama üksnes materiaalse objektina mõelduks), sest tegelikult asub see keerukama aksioloogia keskmes. Klassikaline semiootiline ruut, mis artikuleerib olemuse ja nähtumuse vahelist vastandust, võib sobida "pale-oleku" semiootilise ruudu mudeliks, nii et selles oleks esindatud Nägu, Maskeering (päris maski koht), Võltsing, Anonüümsus. Lähtudes neist teoreetilistest eeldustest pöördutakse artiklis viimaks levimuusika poole ja visandatakse maski pragmaatika provisoorne kaart (lahutav vs liitev, ritualistlik vs kestev, materiaalne vs virtuaalne, mask kui nägu vs nägu kui mask), mis võiks olla aluseks edasistele uuringutele. 